\title{
PENGARUH PERTUMBUHAN PERUSAHAAN DAN PROFITABILITAS TERHADAP STRUKTUR MODAL DAN NILAI PERUSAHAAN
}

\author{
Made Ayu Paramita Dewi ${ }^{1}$ \\ Made Reina Candradewi ${ }^{2}$ \\ ${ }^{1,2}$ Fakultas Ekonomi dan Bisnis Universitas Udayana, Bali, Indonesia \\ email: paramitadewi2205@gmail.com
}

\begin{abstract}
ABSTRAK
Nilai perusahaan adalah harga yang akan dibayarkan oleh pembeli jika suatu perusahaan akan dijual. Pandangan investor terhadap perusahaan akan dilihat dari nilai perusahaan, karena nilai perusaahaan mencerminkan kinerja perusahaan. Agar dapat mengetahui adanya pengaruh dari pertumbuhan perusahaan serta profitabilitas pada struktur modal dan juga nilai perusahaan pada perusahaan industri barang konsumsi di Bursa Efek Indonesia tahun 2014 hingga 2016 merupakan tujuan dari penelitian ini. Penelitian ini menggunakan 36 perusahaan sebagai sampel. Metode purposive sampling digunakan sebagai metode penentuan sampel pada penelitian ini. Penelitian ini menggunakan teknik analisis jalur (path analysis). Hasil yang ditemukan dalam penelitian ini yaitu pertumbuhan perusahaan memiliki pengaruh yang positif dan signifikan terhadap struktur modal dan profitabilitas memiliki pengaruh yang negatif dan signifikan terhadap struktur modal. Pertumbuhan perusahaan tidak memiliki pengaruh terhadap nilai perusahaan, profitabilitas memiliki pengaruh yang positif dan signifikan terhadap nilai perusahaan dan yang terakhir struktur modal memiliki pengaruh yang positif dan signifikan terhadap nilai perusahaan.
\end{abstract}

Kata kunci: pertumbuhan perusahaan, profitabilitas, struktur modal, nilai perusahaan

\begin{abstract}
The value of the company is the price to be paid by the buyer if a company is to be sold. The investor's view of the company will be seen from the value of the company, because the value of the company reflects the company's performance. In order to know the influence of company growth and profitability on capital structure and also company value in consumer goods industry company at Indonesia Stock Exchange year 2014 until 2016 is the purpose of this research. This study used 36 companies as sample. Purposive sampling method is used as sample determination method in this research. This research uses path analysis technique (path analysis). The results found in this study is that the company's growth has a positive and significant influence noncapital structure and profitability have a negative and significant effect on capital structure. Growth of the company has no effect on the value of the company, profitability has a positive and significant impact on the value of the company and the last capital structure has a positive and significantmimpact on the value of the company.
\end{abstract}

Keywords: company growth, profitability, capital structure, the company value 
Made Ayu Paramita Dewi, Pengaruh Pertumbuhan Perusahaan ...

\section{PENDAHULUAN}

Secara normatif tujuan keputusan keuangan adalah untuk memaksimumkan nilai perusahaan atau memaksimumkan kemakmuran pemegang saham. Kemakmuran dari pemilik perusahaan dilihat dari semakin tingginya nilai perusahaan (Wiagustini, 2014:9). Pandangan investor terhadap perusahaan akan

dilihat dari nilai perusahaan, karena nilai perusaahaan mencerminkan kinerja perusahaan (Meidiawati, 2016). Nilai perusahaan menurut Sartono (2014:79) adalah suatu keadaan yang menggambarkan bagaimana masyarakat percaya terhadap apa yang selama ini telah dicapai oleh perusahaan. Pengukuran nilai perusahaan dapat dilihat dari Price Book Value (PBV). PBV adalah perbandingan antara harga pasar per lembar saham dengan nilai buku per saham. Jika perusahaan menunjukkan PBV yang tinggi maka hal tersebut melambangkan kemakmuran pemegang saham (Brigham dan Gapenski, 2006).

Menurut Sartono (2014:371) terdapat beberapa variabel yang mempengaruhi naik turunnya nilai perusahaan yaitu harga pasar saham yang mencerminkan laba potensial, perkembangan perusahaan, dividen, risiko perusahaan, struktur modal dan fakor lainnya seperti kualitas manajemen. Hasil penelitian dari Hermuningsih (2013) menyimpulkan bahwa profitabilitas, pertumbuhan perusahaan dan juga struktur modal mempunyai pengaruh yang positif serta signifikan terhadap nilai perusahaan. Hal yang sama juga ditunjukkan pada penelitian Meidiawati (2016) yang menyatakan bahwa profitabilitas dan struktur modal berpengaruh positif dan juga signifikan terhadap nilai perusahaan. 
Salah satu variabel yang mempengaruhi nilai perusahaan adalah variabel struktur modal. Menurut Sartono (2014:225) struktur modal adalah perbandingan antara jumlah utang jangka pendek yang bersifat permanen, utang jangka panjang, saham preferen serta saham biasa. Penentuan struktur modal yang digunakan di dalam perusahaan akan memiliki dampak langsung pada posisi keuangan perusahaan, sehingga hal tersebut dapat mempengaruhi nilai perusahaan (Susanto, 2016). Pengukuran struktur modal dapat dilihat dari Debt to Equity Ratio (DER) yaitu perbandingan antara total utang dengan total modal sendiri (Sartono, 2014:121). Hasil penelitian dari Ogbulu dan Emeni (2012) menyimpulkan bahwa variabel struktur modal memiliki pengaruh positif dan juga signifikan pada variabel nilai perusahaan. Hermuningsih (2013) juga menjelaskan bahwa struktur modal memiliki pengaruh yang positif dan juga signifikan pada nilai perusahaan. Hasil dari beberapa peneliti lainnya seperti Hoque et al. (2014), Rehman (2016), Dewi dkk. (2016), Meidiawati (2016) dan Riaz dan Qasim (2016) juga menjelaskan bahwa struktur modal memiliki pengaruh yang positif dan juga signifikan pada nilai perusahaan. Pada sisi lain, hal yang berbeda ditunjukkan oleh penelitian Shun-Yu dan Li-Ju (2011) serta Li-Ju dan Shun-Yu (2011) yang menyimpulkan bahwa variabel struktur modal berpengaruh negatif dan signifikan terhadap variabel nilai perusahaan. Hasil penelitian yang dilakukan oleh Fau (2015) serta Dewi dan Sudiartha (2017) juga menyatakan bahwa struktur modal berpengaruh negatif signifikan terhadap nilai perusahaan. Hasil penelitian dari Ayako dan Wamalwa (2015), Ulum (2015) dan Susanto (2016) menyatakan hal yang berbeda yaitu struktur modal tidak berpengaruh terhadap nilai perusahaan. 
Menurut Sartono (2014:248) terdapat berbagai faktor penting yang harus diperhitungkan dalam menetapkan struktur modal salah satunya yaitu pertumbuhan perusahaan. Brigham dan Houston (2011:189) mengatakan bahwa dalam pecking order theory dana yang harus digunakan dahulu adalah dana dari dalam perusahaan, tetapi bila tidak juga mencukupi, maka hutang merupakan alternatif pertama. Tingginya pertumbuhan pada perusahaan mengharuskan perusahaan untuk menggunakan dana dari luar perusahaan, karena jika pertumbuhan perusahaan tinggi maka kebutuhan dana untuk membiayai ekspansi semakin besar. Penelitian dari Cortez dan Susanto (2012) menjelaskan bahwa variabel pertumbuhan perusahaan berpengaruh positif dan signifikan terhadap variabel struktur modal. Hasil dari Hermuningsih (2013) serta Akinyomi dan Olagunju (2013) menjelaskan jika pertumbuhan perusahaan memiliki pengaruh yang positif dan signifikan pada struktur modal. Daskalakis et al. (2014) dan Karacaer et al. (2016) juga menyatakan bahwa pertumbuhan perusahaan berpengaruh positif dan signifikan terhadap struktur modal. Pada sisi lain, hal yang berbeda ditunjukkan oleh penelitian Shun-Yu dan Li-Ju (2011) yang menyimpulkan bahwa variabel pertumbuhan perusahaan berpengaruh negatif signifikan terhadap struktur modal. Penelitian dari Ahmadimoussabad (2013) juga menyatakan pertumbuhan perusahaan berpengaruh negatif dan signifikan terhadap struktur modal. Penelitian lainnya yang dilakukan oleh Susanto (2016), Wardhani (2016) dan Dewi dan Sudiartha (2017) menyatakan bahwa pertumbuhan perusahaan tidak berpengaruh terhadap struktur modal. 
Nilai perusahaan juga dipengaruhi oleh pertumbuhan perusahaan (Sartono, 2014:371). Pertumbuhan perusahaan diukur menggunakan pertumbuhan total aktivanya. Total Asset Growth (TAG) adalah selisih total aktiva pada masa sekarang dengan masa sebelumnya terhadap total aktiva pada masa sebelumnya (Dewi dan Sudiartha, 2017). Pertumbuhan pada aset perusahaan yang tinggi akan melambangkan perkembangan perusahaan yang baik secara internal maupun eksternal (Dewi dan Sudiartha, 2017). Hal ini menyebabkan banyaknya investasi yang didapatkan perusahaan. Permintaan terhadap saham perusahaan meningkat dan hal tersebut akan menyebabkan nilai perusahaan juga meningkat. (Susanto, 2016). Hasil penelitian yang dilakukan oleh Kusumajaya (2011) menjelaskan bahwa variabel pertumbuhan perusahaan memiliki pengaruh yang positif dan juga signifikan pada variabel nilai perusahaan. Febrianti (2012) dan Hestinoviana dkk. (2012) juga menyimpulkan bahwa pertumbuhan perusahaan memiliki pengaruh yang positif dan juga signifikan pada nilai perusahaan. Hasil dari Hermuningsih (2013) dan Dewi dkk. (2016) yang menyatakan bahwa pertumbuhan perusahaan berpegaruh positif dan signifikan terhadap nilai perusahaan. Pada sisi lain, hal yang berbeda ditunjukkan oleh penelitian Shun-Yu dan Li-Ju (2011) yang menjelaskan bahwa variabel pertumbuhan perusahaan memiliki pengaruh yang negatif dan signifikan pada variabel nilai perusahaan. Penelitian dari Susanto (2016) juga menyatakan bahwa pertumbuhan perusahaan berpengaruh negatif terhadap nilai perusahaan. Hasil yang berbeda ditemukan pada penelitian Fau (2015), Riaz dan Qasim (2016), Sudiani dan Darmayanti (2016), Meidiawati 
Made Ayu Paramita Dewi, Pengaruh Pertumbuhan Perusahaan ...

(2016) serta Dewi dan Sudiartha (2017) menjelaskan jika pertumbuhan perusahaan tidak memiliki pengaruh pada nilai perusahaan.

Selain pertumbuhan perusahaan, profitabilitas juga merupakan faktor yang mempengaruhi struktur modal dan nilai perussahaan. Menurut Sartono (2014:76), profitabilitas adalah kemampuan perusahaan dalam menghasilkan keuntungan yang berhubungan dengan penjualan, total aktiva serta modal sendiri. Perusahaan yang profitabilitasnya tinggi akan lebih sedikit menggunakan utang karena perusahaan sudah memiliki laba ditahan yang tinggi untuk mendanai kegiatan perusahaannya. Hasil penelitian yang dilakukan oleh Akinyomi dan Olagunju (2013) serta Wardhani (2016) menyimpulkan bahwa variabel profitabilitas berpengaruh positif dan signifikan terhadap variabel struktur modal. Penelitian yang dilakukan oleh Gamaliel dan Sudjarni (2015) serta Kartika dan Dana (2015) juga menjelaskan bahwa profitabilitas berpengaruh positif signifikan terhadap struktur modal. Sejalan dengan penelitian Dewi dan Sudiartha (2017) juga menyatakan bahwa profitabilitas berpengaruh positif dan signifikan terhadap struktur modal. Pada sisi lain, hal yang berbeda ditunjukkan oleh penelitian ShunYu dan Li-Ju (2011) serta Li-Ju dan Shun-Yu (2011) menjelaskan bahwa variabel profitabilitas berpengaruh negatif terhadap variabel struktur modal. Cortez dan Susanto (2012) juga menyimpulkan bahwa profitabilitas berpengaruh negatif signifikan terhadap struktur modal. Sejalan dengan penelitian sebelumnya Hermuningsih (2013), Ahmadimousaabad (2013), Daskalakis et al. (2014), Karacaer et al. (2016) dan Susanto (2016) juga menyatakan bahwa profitabilitas berpengaruh negatif dan signifikan terhadap struktur modal. 
Tingginya nilai profitabilitas menunjukkan kinerja perusahaan meningkat dan diperkirakan perusahaan mempunyai prospek masa depan yang baik sehingga permintaan akan saham perusahaan juga naik yang pada akhirnya akan meningkatkan nilai perusahaan (Susanto, 2016). Menurut Sartono (2014:76) profitabilitas dapat diukur dengan mengunakan Return on Equity (ROE). Return on Equity (ROE) adalah perbandingan antara keuntungan setelah pajak yang dihasilkan perusahaan terhadap modal sendiri. ROE memperlihatkan kemampuan perusahaan dalam memperoleh keuntungan yang nantinya akan diperuntukkan bagi pemegang saham. Hasil penelitian yang dilakukan oleh Shun-Yu dan Li-Ju (2011) serta Li-Ju dan Shun-Yu (2011) menyimpulkan bahwa variabel profitabilitas berpengaruh positif dan signifikan terhdap variabel nilai perusahaan. Penelitian dari Hermuningsih (2013), Fau (2015) dan Ulum (2015) juga menjelaskan bahwa profitabilitas berpengaruh positif signifikan terhadap nilai perusahaan. Sejalan dengan penelitian sebelumnya Sudiani dan Darmayanti (2016), Dewi dkk. (2016), Meidiawati (2016), Lestari dan Armayah (2016), Riaz dan Qasim (2016), serta Dewi dan Sudiartha (2017) juga menjelaskan jika profitabilitas memiliki pengaruh yang positif dan juga signifikan pada nilai perusahaan. Pada sisi lain, hal yang berbeda ditunjukkan oleh penelitian Juhandi dkk. (2013) menyimpulkan bahwa variabel profitabilitas berpengaruh negatif signifikan terhadap variabel nilai perusahaan. Herawati (2013) juga menjelaskan bahwa profitabilitas berpengaruh negatif signifikan terhadap nilai perusahaan. Penelitian yang dilakukan oleh Anzlina dan Rustam (2013) serta Susanto (2016) juga menyatakan hal yang sama, dimana profitabilitas berpegaruh negatif dan juga 
signifikan pada nilai perusahaan. Penelitian dari Hestinoviana (2012) menyatakan hal yang berbeda bahwa profitabilitas tidak berpegaruh terhadap nilai perusahaan.

Perusahaan manufaktur yang terdapat di Bursa Efek Indonesia (BEI) dibagi menjadi beberapa sektor salah satunya industri barang konsumsi. Perusahaan industri barang konsumsi barangnya setiap hari dikonsumsi oleh masyarakat luas, sehingga secara tidak langsung akan meningkatkan harga saham juga akan menyebabkan meningkatnya nilai perusahaan.

Brigham dan Houston (2011:189) mengatakan bahwa dalam pecking order theory dana yang harus digunakan dahulu adalah dana dari dalam perusahaan, tetapi bila tidak juga mencukupi, maka hutang merupakan alternatif pertama. Tingginya pertumbuhan pada perusahaan mengharuskan perusahaan untuk menggunakan dana dari luar perusahaan, karena jika pertumbuhan perusahaan tinggi maka dana yang dibutuhkan untuk membiayai ekspansi semakin besar. Perusahaan-perusahaan dengan tingkat pertumbuhan yang lambat akan menggunakan sedikit hutang dibandingkan dengan perusahaan yang pertumbuhannya lebih cepat (Hermuningsih, 2013). Hal tersebut sejalan dengan penelitian Akinyomi dan Olagunju (2013), Daskalakis et al. (2014), dan Karacaer et al. (2016).

$\mathrm{H}_{1}$ :Pertumbuhan Perusahaan berpengaruh positif dan signifikan pada Struktur Modal.

Menurut Sartono (2014:76), profitabilitas merupakan kemampuan perusahaan dalam memperoleh keuntungan yang berhubungan dengan penjualan, total aktiva serta modal sendiri. Perusahaan yang profitabilitasnya tinggi akan lebih sedikit menggunakan utang karena perusahaan sudah memiliki laba ditahan 
yang tinggi untuk mendanai kegiatan operasional perusahaannya. Perusahaan yang mempunyai posisi keuangan yang baik tidak akan banyak menggunakan walaupun memiliki kesempatan untuk menggunakan hutang yang lebih banyak. Oleh karena itu, profitabilitas yang tinggi pada perusahaan akan berlawanan dengan DER. Hal tersebut sejalan dengan penelitian Hermuningsih (2013), Daskalakis et al. (2014), dan Karacaer et al. (2016).

$\mathrm{H}_{2}$ : Profitabilitas berpengaruh negatif dan signifikan terhadap Struktur Modal.

Pertumbuhan perusahaan dapat dilihat melalui naik atau turunnya total aset periode saat ini dibandingkan dengan periode sebelumnya. Pertumbuhan perusahaan melambangkan perkembangan yang baik bagi perusahaan dan hal tersebut sangat diharapkan oleh pihak-pihak yang terkait di dalam perusahaan baik internal maupun pihak eksternal. Investor luar yang melihat pertumbuhan aktiva tersebut akan tertarik pada perusahaan karena akan mencerminkan perusahaan mampu untuk memperoleh laba yang digunakan untuk menambah jumlah aktivanya sehingga hal tersebut akan meningkatkan nilai perusahaan (Meidiawati, 2016). Jika permintaan saham dari investor terhadap saham perusahaan tersebut tinggi maka hal tersebut akan mempengaruhi harga saham. Jika harga saham perusahaan meningkat maka akan meningkatkan nilai perusahaan (Fau, 2015). Hal tersebut juga sejalan dengan penelitian Hestinoviana dkk. (2012) dan Hermuningsih (2013).

$\mathrm{H}_{3}$ :Pertumbuhan Perusahaan berpengaruh positif dan signifikan terhadap Nilai Perusahaan. 
Profitabilitas perusahaan dapat digunakan untuk menilai seberapa banyak yang akan didapatkan perusahaan melalui aktivitas investasi yang dilakukannya. Saat perusahaan dikatakan menguntungkan dan mempunyai peluang yang bagus di masa depan maka investor akan berlomba-lomba untuk membeli saham tersebut. Banyaknya permintaan akan saham perusahaan akan membuat harga saham meningkat dan pada akhirnya membuat nilai perusahaan meningkat (Brigham dan Gapenski, 2006). Jadi tingginya nilai profitabilitas menunjukkan kinerja perusahaan meningkat dan diperkirakan perusahaan mempunyai prospek masa depan yang baik sehingga permintaan akan saham perusahaan juga naik yang pada akhirnya akan meningkatkan nilai perusahaan (Susanto, 2016). Hal tersebut juga sejalan dengan penelitian Hermuningsih (2013), Fau (2015), Ulum (2015), Meidiawati (2016), Lestari dan Armayah (2016), Riaz dan Qasim (2016), dan Dewi dan Sudiartha (2017).

$\mathrm{H}_{4}$ :Profitabilitas memiliki pengaruh yang positif dan juga signifikan terhadap Nilai Perusahaan.

Dalam keadaan ada pajak, Modigliani dan Miller dalam Husnan dan Pudjiastuti (2012:269) berpendapat bahwa keputusan pendanaan yang dilakukan perusahaan menjadi relevan. Saat perusahaan menggunakan hutang maka perusahaan pada umumnya akan membayarkan bunga dari hutang yang digunakannya. Pembayaran bunga tersebut dapat digunakan untuk mengurangi penghasilan perusahaan yang seharusnya dikenakan pajak (bersifat tax deductible). Jika dibandingkan antara dua perusahaan, dimana perusahaan menghasilkan laba yang sama, tetapi salahsatunya berhutang dan harus membayarkan bunganya sedangkan satunya tidak berhutang, maka pajak 
penghasilan (income tax) yang dibayarkan perusahaan yang membayar bunga akan lebih kecil. Penghematan pembayaran pajak tersebut dapat menjadi keuntungan bagi perusahaan. Nilai perusahaan saat tidak berhutang akan menjadi rendah daripada nilai perusahaan yang berhutang. Hal tersebut juga sejalan dengan penelitian Hoque et al. (2014), Rehman (2016), Meidiawati (2016) dan Riaz dan Qasim (2016).

$\mathrm{H}_{5}$ :Struktur Modal berpengaruh positif dan signifikan terhadap Nilai Perusahaan.

\section{METODE PENELITIAN}

Penelitian ini merupakan penelitian kausalitas yaitu untuk mengetahui hubungan sebab akibat antara variabel pertumbuhan perusahaan dan profitabilitas terhadap struktur modal dan nilai perusahaan. Penelitian ini dilakukan pada perusahaan Industri Barang Konsumsi di Bursa Efek Indonesia melalui situs www.idx.co.id. Obyek dari penelitian ini adalah variabel yang mempengaruhi struktur modal dan nilai perusahaan yang diantaranya adalah pertumbuhan perusahaan dan profitabilitas pada perusahaan Industri Barang Konsumsi di Bursa Efek Indonesia periode tahun 2014-2016. Variabel eksogen dalam penelitian ini adalah Pertumbuhan Perusahaan $\left(\mathrm{X}_{1}\right)$ dan Profitabilitas $\left(\mathrm{X}_{2}\right)$. Variabel intervening dalam penelitian ini adalah Struktur Modal $\left(\mathrm{Y}_{1}\right)$ dan variabel endogen dalam penelitian ini adalah Nilai Perusahaan $\left(\mathrm{Y}_{2}\right)$.

Nilai perusahaan diukur dengan Price Book Value (PBV) yaitu perbandingan antara harga pasar per lembar saham dengan nilai buku pada Perusahaan Industri Barang Konsumsi di Bursa Efek Indonesia Periode 20142016. Hasil dari perhitungan Price Book Value (PBV) dalam bentuk X (kali). 


$$
\text { PBV }=\frac{\text { Harga pasar per lembar saham }}{\text { Nilai buku }}
$$

Struktur modal diukur dengan Debt to Equity Ratio (DER) yaitu perbandingan antara total utang dengan total modal sendiri pada Perusahaan Industri Barang Konsumsi di Bursa Efek Indonesia Periode 2014-2016. Hasil dari perhitungan Debt to Equity Ratio (DER) dalam bentuk \% (persentase).

$$
\mathrm{DER}=\frac{\text { Total Utang }}{\text { Total Modal Sendiri }} \times 100 \%
$$

Pertumbuhan Perusahaan dihitung dari pertumbuhan total aktivanya. Total Asset Growth (TAG) adalah hasil dari pengurangan total aktiva yang dimiliki oleh perusahaan pada masa sekarang dengan masa sebelumnya terhadap total aktiva masa sebelumnya pada Perusahaan Industri Barang Konsumsi di Bursa Efek Indonesia Periode 2014-2016. Hasil dari perhitungan Total Asset Growth (TAG) dalam bentuk \% (persentase).

$$
\text { TAG }=\frac{\text { Total Aset }_{\mathrm{t}} \text { - }^{\text {Total Aset }}{ }_{\mathrm{t}-1}}{\text { Total Aset }_{\mathrm{t}-1}} \times 100 \%
$$

Profitabilitas dihitung dengan Return on Equity (ROE) yaitu perbandingan antara keuntungan setelah pajak dengan modal sendiri pada Perusahaan Industri Barang Konsumsi di Bursa Efek Indonesia Periode 2014-2016. Hasil dari perhitungan Return on Equity (ROE) dalam bentuk \% (persentase).

$$
\mathrm{ROE}=\frac{\text { Laba Setelah Pajak }}{\text { Modal Sendiri }} \times 100 \%
$$

Perusahaan Industri Barang Konsumsi di Bursa Efek Indonesia yang berjumlah 38 perusahaan selama tahun 2014 hingga 2016 merupakan populasi dipenelitian ini. Sampel yang diambil menggunakan metode purposive sampling 
dalam penentuan sampelnya. Tabel 1 menunjukkan proses pemilihan perusahaan sampel. Berdasarkan data tersebut, sampel yang digunakan dalam penelitian ini berjumlah 36 perusahaan industri barang konsumsi periode 2014-2016.

Tabel 1.

Proses Pemilihan Perusahaan Sampel=

\begin{tabular}{lc}
\hline \multicolumn{1}{c}{ Keterangan } & Jumlah Perusahaan \\
\hline Perusahaan industri barang konsumsi yang terdaftar di & 38 \\
BEI (populasi) & $(2)$ \\
\hline Perusahaan industri barang konsumsi yang terdaftar di & \\
BEI periode 2014-2016 & $\mathbf{3 6}$
\end{tabular}

Sumber: Data sekunder diolah, 2018

Penelitian ini menggunakan data kualitatif dan kuantitatif berupa laporan keuangan dari perusahaan Industri Barang Konsumsi di Bursa Efek Indonesia. Penelitian ini menggunakan sumber sekunder, dimana data didapatkan melalui situs Bursa Efek Indonesia (BEI) yaitu www.idx.co.id untuk memperoleh data laporan keuangan perusahaan pada Perusahaan Industri Barang Konsumsi. Metode observasi non participant digunakan dalam pengumpulan data penelitian ini.

Teknik analisis jalur atau path analysis adalah teknik analisis data yang digunakan untuk menguji bagaimana pengaruh pertumbuhan perusahaan dan profitabilitas terhadap struktur modal dan nilai perusahaan. Sebelumnya dilakukan uji asumsi klasik terlebuh dahulu yaitu uji normalitas, multikolinearitas, heteroskedastisitas dan autokorelasi yang bertujuan untuk mendapat nilai parameter penduga yang sah. Proses sebab akibat yang bertujuan untuk menganalisis serta menginterpretasikan hubungan antar variabel yang dihipotesiskan dinamakan diagram jalur (Kuncoro dan Riduan, 2011:2). Secara 
teoritis hubungan antar variabel tersebut, maka dibuatlah model dalam diagram jalur.

Struktur 1: $\mathrm{Y}_{1}=\rho_{\mathrm{y} 1 \mathrm{x} 1}+\rho_{\mathrm{y} 1 \mathrm{x} 2}+\rho_{\mathrm{y} 1 \mathrm{e} 1 \ldots \ldots \ldots \ldots \ldots \ldots \ldots \ldots \ldots \ldots \ldots \ldots \ldots \ldots \ldots \ldots \ldots \ldots \ldots}(5)$

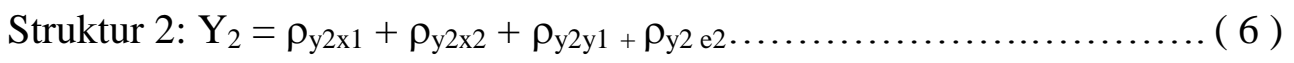

Keterangan: $\quad \rho i\left(x_{1,2,3,4}\right)(y 1,2)=$ koefisien jalur

$$
\mathrm{e}=(1,2)=\text { standard error of the estimate }
$$

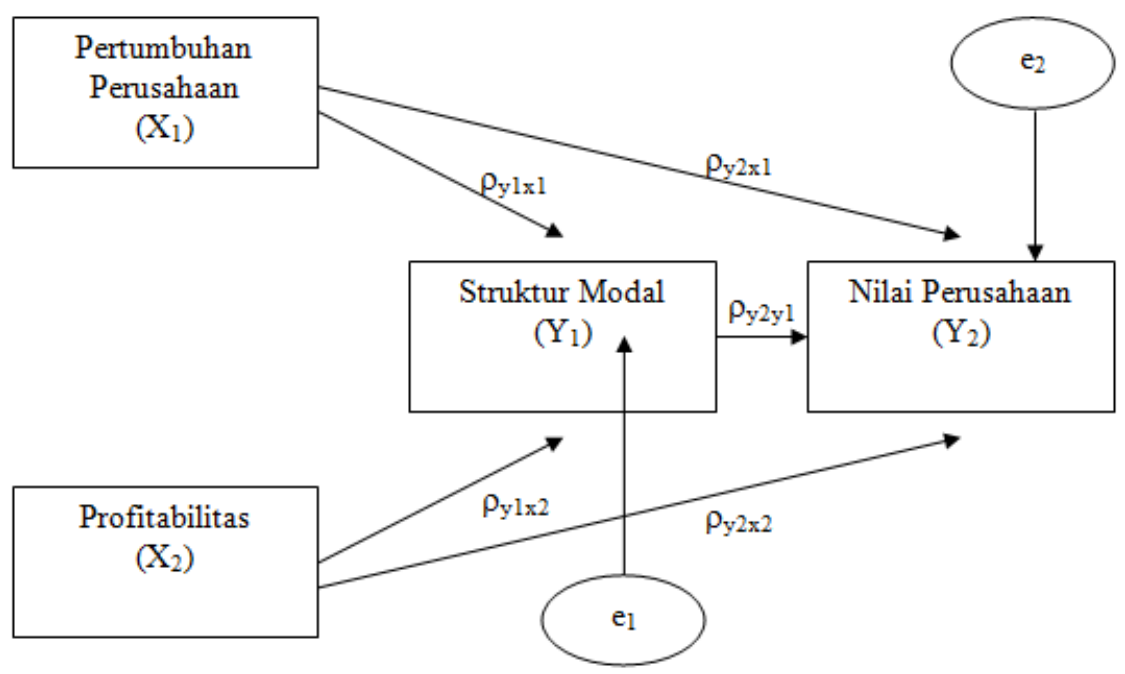

Gambar 1. Model Jalur Pengaruh Pertumbuhan Perusahaan $\left(X_{1}\right)$ dan Profitabilitas $\left(X_{2}\right)$ Pada Struktur Modal $\left(Y_{1}\right)$ dan Nilai Perusahaan $\left(\mathbf{Y}_{2}\right)$.

Sumber: Data sekunder diolah, 2018

\section{HASIL DAN PEMBAHASAN}

Hasil dari analisis statistik deskriptif memperlihatkan jumlah data yang digunakan dalam penelitian, nilai minimum, nilai maksimum, mean (rata-rata), dan deviasi standar. 
Tabel 2.

Hasil Analisis Statistik Deskriptif

\begin{tabular}{lrrrrr}
\hline & N & Minimum & Maximum & \multicolumn{1}{c}{ Mean } & \multicolumn{1}{c}{$\begin{array}{c}\text { Std. } \\
\text { Deviation }\end{array}$} \\
\hline N Valid & 108 & & & & \\
TAG (\%) & 108 & $-17,53$ & 92,19 & 9,7349 & 12,97811 \\
ROE (\%) & 108 & $-16,67$ & 138,12 & 15,5371 & 17,73026 \\
DER (\%) & 108 & 4,78 & 171,20 & 73,8469 & 41,16190 \\
PBV (X) & 108 & 0,01 & 27,35 & 3,4004 & 3,85445 \\
\hline
\end{tabular}

Sumber: Data sekunder diolah, 2018

Tabel 2 menunjukkan bahwa jumlah data yang digunakan dalam penelitian ini sebanyak 108 sampel, maka dapat dijelaskan sebagai berikut :

Variabel Pertumbuhan Perusahaan (TAG) memiliki nilai rata-rata sebesar $9,7349 \%$ dan memiliki standar deviasi sebesar $12,97811 \%$. Nilai minimum sebesar -17,53\% dimiliki oleh Tri Banyan Tirta Tbk. pada tahun 2014 sedangkan nilai maksimum sebesar 92,19\% dimiliki oleh Budi Starch \& Sweetener Tbk. pada tahun 2014.

Variabel Profitabilitas (ROE) memiliki nilai rata-rata sebesar $15,5371 \%$ dan memiliki standar deviasi sebesar $17,73026 \%$. Nilai minimum sebesar $-16,67 \%$ dimiliki oleh Bentoel Internasional Investama Tbk. pada tahun 2016 sedangkan nilai maksimum sebesar 138,12\% dimiliki Merck Sharp Dohme Pharma Tbk. oleh pada tahun 2015 .

Variabel Struktur Modal (DER) memiliki nilai rata-rata sebesar 73,8469\% dan memiliki standar deviasi sebesar 41,16190\%. Nilai minimum sebesar 4,78\% dimiliki oleh Merck Sharp Dohme Pharma Tbk. pada tahun 2016 sedangkan nilai maksimum sebesar 171,20\% dimiliki oleh Budi Starch \& Sweetener Tbk. pada tahun 2014. 
Made Ayu Paramita Dewi, Pengaruh Pertumbuhan Perusahaan ...

Variabel Nilai Perusahaan (PBV) memiliki nilai rata-rata sebesar 3,4004 kali dan memiliki standar deviasi sebesar 3,85445 kali. Nilai minimum sebesar 0,01 kali dimiliki oleh Tri Banyan Tirta Tbk. pada tahun 2016 sedangkan nilai maksimum sebesar 27,35 kali dimiliki oleh HM Sampoerna Tbk. pada tahun 2014

Analisis jalur (path analysis) menggunakan dua tahap uji asumsi klasik. Model pertama pada $\left(\mathrm{Y}_{1}\right)$ untuk menguji variabel eksogen Pertumbuhan Perusahaan (TAG) dan Profitabilitas (ROE) terhadap variabel endogen Struktur Modal (DER). Model kedua pada $\left(\mathrm{Y}_{2}\right)$ untuk menguji variabel eksogen Pertumbuhan Perusahaan (TAG), Profitabilitas (ROE) dan Struktur Modal (DER) terhadap variabel endogen Nilai Perusahaan (PBV).

Uji normalitas digunakan untuk apakah data yang diteliti sudah berdistribusi normal ataukah tidak.

Tabel 3.

Uji Normalitas Model Pertama One-Sample Kolmogorov-Smirnov Test

\begin{tabular}{|c|c|c|}
\hline & & Unstandardized Residual \\
\hline $\mathrm{N}$ & & 108 \\
\hline \multirow{2}{*}{ Normal Parameters ${ }^{\mathrm{a}, \mathrm{b}}$} & Mean &, 0000000 \\
\hline & Std. Deviation & 38,63148150 \\
\hline Most Extreme & Absolute & , 103 \\
\hline \multirow[t]{2}{*}{ Differences } & Positive & , 103 \\
\hline & Negative &,- 082 \\
\hline Kolmogorov-Smirnov & & 1,075 \\
\hline Asymp. Sig. (2 -tailed) & & ,198 \\
\hline
\end{tabular}

a. Test distribution is Normal

Sumber: Data sekunder diolah, 2018

Pada Tabel 3 menunjukkan hasil output SPSS model pertama, dimana Asymp. Sig. (2-tailed) menunjukkan angka sebesar 0,198>0,05 ,maka menunjukkan bahwa data berdistribusi normal dan model pertama dinyatakan memenuhi uji normalitas. 
Tabel 4.

Uji Normalitas Model Kedua

One-Sample Kolmogorov-Smirnov Test

\begin{tabular}{llr}
\hline & & Unstandardized Residual \\
\hline $\mathrm{N}$ & & 108 \\
Normal Parameters ${ }^{\mathrm{a}, \mathrm{b}}$ & Mean &,- 2580318 \\
& Std. Deviation & 1,96478640 \\
Most Extreme & Absolute &, 083 \\
Differences & Positive &, 083 \\
& Negative &,- 076 \\
Kolmogorov-Smirnov Z & &, 862 \\
Asymp. Sig. (2-tailed) & &, 447 \\
\hline
\end{tabular}

a. Test distribution is Normal

Sumber: Data sekunder diolah, 2018

Pada Tabel 4 menunjukkan hasil output SPSS model kedua, dimana Asymp.

Sig. (2-tailed) menunjukkan angka sebesar 0,447 > 0,05 ,maka menunjukkan bahwa data berdistribusi normal dan model kedua dinyatakan memenuhi uji normalitas.

Uji multikolinearitas bertujuan untuk menguji apakah pada model regresi ditemukan adanya korelasi antar variabel bebas.

\section{Tabel 5.}

Uji Multikolinearitas Model Pertama Coefficients $^{\mathrm{a}}$

\begin{tabular}{llrr}
\hline & & \multicolumn{2}{c}{ Collinearity Statistics } \\
\cline { 3 - 4 } Model & \multicolumn{2}{c}{ Tolerance } & VIF \\
\hline 1 & TAG (\%) &, 994 & 1,006 \\
& ROE (\%) &, 994 & 1,006 \\
\hline
\end{tabular}

a. Dependent Variable: DER (\%)

Sumber: Data sekunder diolah, 2018

Pada Tabel 5 menunjukkan hasil output SPSS model pertama, pada variabel pertumbuhan perusahaan (TAG) memiliki nilai tolerance sebesar 0,994 dan variabel profitabilitas (ROE) memiliki nilai tolerance sebesar 0,994 yang lebh besar dari $10 \%(0,10)$. Sedangkan pada varibel pertumbuhan perusahaan (TAG) memiliki VIF sebesar 1,006 dan variabel pertumbuhan perusahaan (TAG) 
memiliki VIF sebesar 1,006 yang lebih kecil dari 10, maka dari itu dapat disimpulkan bahwa model pertama tidak ada multikolinearitas.

Tabel 6.

Uji Multikolinearitas Model Kedua Coefficients $^{\mathrm{a}}$

\begin{tabular}{|c|c|c|c|}
\hline \multirow[b]{2}{*}{ Model } & & \multicolumn{2}{|c|}{ Collinearity Statistics } \\
\hline & & Tolerance & VIF \\
\hline 1 & TAG (\%) & ,931 & 1,075 \\
\hline & $\operatorname{ROE}(\%)$ & ,923 & 1,084 \\
\hline & $\operatorname{DER}(\%)$ & ,881 & 1,135 \\
\hline
\end{tabular}

a. Dependent Variable: PBV (X)

Sumber: Data sekunder diolah, 2018

Pada Tabel 6 menunjukkan hasil output SPSS model kedua, pada variabel pertumbuhan perusahaan (TAG) memiliki nilai tolerance sebesar 0,931 , variabel profitabilitas (ROE) memiliki nilai tolerance sebesar 0,923 dan variabel struktur modal (DER) memiliki nilai tolerance sebesar 0,881 yang lebh besar dari 10\% $(0,10)$. Sedangkan pada varibel pertumbuhan perusahaan (TAG) memiliki VIF sebesar 1,075, variabel pertumbuhan perusahaan (TAG) memiliki VIF sebesar 1,084 dan variabel struktur modal (DER) memiliki VIF sebesar 1,135 yang lebih kecil dari 10, maka dari itu dapat disimpulkan bahwa model kedua tidak ada multikolinearitas.

Uji heteroskedastisitas bertujuan menguji apakah dalam model regresi terjadi ketidaksamaan varians dari residual satu pengamatan ke pengamatan yang lain. Uji Glejser yakni dengan cara meregresi nilai absolute residual dari model yang diestimasi terhadap variabel independen. 
Tabel 7

Uji Heteroskedastisitas Model Pertama

Coefficients $^{\mathrm{a}}$

\begin{tabular}{|c|c|c|c|c|c|c|}
\hline \multirow{2}{*}{\multicolumn{2}{|c|}{ Model }} & \multicolumn{2}{|c|}{$\begin{array}{l}\text { Unstandardized } \\
\text { Coefficients }\end{array}$} & \multirow{2}{*}{$\begin{array}{l}\text { Standardized } \\
\text { Coefficients } \\
\text { Beta }\end{array}$} & \multirow[b]{2}{*}{$\mathrm{t}$} & \multirow[b]{2}{*}{ Sig. } \\
\hline & & B & Std. Error & & & \\
\hline \multirow[t]{3}{*}{1} & (Constant) & 36,092 & 2,912 & & 12,394 & ,000 \\
\hline & TAG (\%) &,- 108 &, 151 &,- 069 &,- 716 & ,476 \\
\hline & ROE (\%) &,- 147 & , 110 &,- 129 & $-1,329$ & 187 \\
\hline
\end{tabular}

a. Dependent Variable: Absolut Residual

Sumber: Data sekunder diolah, 2018

Pada Tabel 7 menunjukkan hasil output SPSS model pertama, dimana nilai signifikansi dari variabel pertumbuhan perusahaan (TAG) sebesar 0,476 dan variabel profitabilitas (ROE) sebesar 0,187 yang menunjukkan angka lebih besar dari 5\% (0,05), maka dari itu dapat disimpulkan bahwa model pertama tidak terjadi heteroskedastisitas.

\section{Tabel 8}

\section{Uji Heteroskedastisitas Model Kedua} Coefficients $^{\mathrm{a}}$

\begin{tabular}{|c|c|c|c|c|c|c|}
\hline \multirow{2}{*}{\multicolumn{2}{|c|}{ Model }} & \multicolumn{2}{|c|}{$\begin{array}{l}\text { Unstandardized } \\
\text { Coefficients }\end{array}$} & \multirow{2}{*}{$\begin{array}{l}\text { Standardized } \\
\text { Coefficients } \\
\text { Beta }\end{array}$} & \multirow[b]{2}{*}{$\mathrm{t}$} & \multirow[b]{2}{*}{ Sig. } \\
\hline & & $\mathrm{B}$ & Std. Error & & & \\
\hline \multirow[t]{4}{*}{1} & (Constant) & 1,384 & ,296 & & 4,674 & ,000 \\
\hline & TAG (\%) &,- 008 & ,010 &,- 079 &,- 783 & ,436 \\
\hline & ROE (\%) &, 004 & ,007 & ,061 &, 600 &, 550 \\
\hline & DER $(\%)$ & ,002 & ,003 &, 076 & ,729 & ,467 \\
\hline
\end{tabular}

a. Dependent Variable: Absolut Residual

Sumber: Data sekunder diolah, 2018

Pada Tabel 8 menunjukkan hasil output SPSS model kedua, dimana nilai signifikansi dari variabel pertumbuhan perusahaan (TAG) sebesar 0,436, variabel profitabilitas (ROE) sebesar 0,550 dan variabel struktur modal (DER) sebesar 0,467 yang menunjukkan angka lebih besar dari 5\% $(0,05)$, maka dari itu dapat disimpulkan bahwa model kedua tidak terjadi heteroskedastisitas.

Uji autokorelasi bertujuan untuk melacak adanya korelasi auto atau pengaruh data dari pengamatan sebelumnya dalam suatu model regresi. Uji 
autokorelasi dapat dilakukan dengan menggunakan Uji Durbin-Watson (DW-test) (Utama, 2014:103).

\section{Tabel 9}

Uji Autokorelasi Model Pertama Model Summary ${ }^{\mathrm{b}}$

\begin{tabular}{cccccc}
\hline Model & R & R Square & $\begin{array}{c}\text { Adjusted R } \\
\text { Square }\end{array}$ & $\begin{array}{c}\text { Std.Error of the } \\
\text { Estimate }\end{array}$ & $\begin{array}{c}\text { Durbin- } \\
\text { Watson }\end{array}$ \\
\hline 1 &, $345^{\mathrm{a}}$ &, 119 &, 102 & 38,99766 & 1,801 \\
\hline
\end{tabular}

a. Predictors: (Constant), ROE (\%), TAG (\%)

b. Dependent Variable: DER (\%)

Sumber: Data sekunder diolah, 2018

Pada Tabel 9 menunjukkan hasil output SPSS model pertama, dimana nilai Durbin-Watson-nya sebesar 1,801. Berdasarkan nilai signifikansi 5\% $(0,05)$, untuk jumlah data sebanyak 108 dan jumlah variabel eksogen $(\mathrm{k}=2)$, maka $\mathrm{d}_{\mathrm{L}}=$ 1,64 dan $d_{u}=1,72$. Nilai Durbin-Watson model pertama sebesar 1,801 lebih besar dari nilai $\mathrm{d}_{\mathrm{u}}=1,72$ dan lebih kecil dari nilai $4-\mathrm{d}_{\mathrm{u}}=2,28$, maka tidak ada autokorelasi.

\begin{tabular}{|c|c|c|c|c|c|}
\hline \multicolumn{6}{|c|}{$\begin{array}{c}\text { Tabel } 10 \\
\text { Uji Autokorelasi Model Kedua } \\
\text { Model Summary }\end{array}$} \\
\hline Model & $\mathrm{R}$ & R Square & $\begin{array}{c}\text { Adjusted R } \\
\text { Square }\end{array}$ & $\begin{array}{l}\text { Std. Error of } \\
\text { the Estimate }\end{array}$ & $\begin{array}{l}\text { Durbin- } \\
\text { Watson }\end{array}$ \\
\hline 1 &, $379^{\mathrm{a}}$ &, 143 &, 119 & 3,61831 & 2,044 \\
\hline
\end{tabular}

Pada Tabel 10 menunjukkan hasil output SPSS model kedua, dimana nilai Durbin-Watson-nya sebesar 2,044. Berdasarkan nilai signifikansi 5\% $(0,05)$, untuk jumlah data sebanyak 108 dan jumlah variabel eksogen $(k=3)$, maka $d_{L}=$ 1,62 dan $d_{u}=1,74$. Nilai Durbin-Watson model kedua sebesar 2,044 lebih besar 
dari nilai $\mathrm{d}_{\mathrm{u}}=1,74$ dan lebih kecil dari nilai $4-\mathrm{d}_{\mathrm{u}}=2,26$, maka tidak ada autokorelasi.

Langkah dalam analisis jalur (path analysis) yaitu pengujian koefisien jalur secara individu dari variabel pertumbuhan perusahaan, profitabilitas dan struktur modal pada nilai perusahaan.

Tabel 11

Koefisien Regresi Model Pertama Coefficients $^{\mathrm{a}}$

\begin{tabular}{|c|c|c|c|c|c|c|}
\hline \multirow[b]{2}{*}{ Model } & & \multicolumn{2}{|c|}{$\begin{array}{l}\text { Unstandardized } \\
\text { Coefficients }\end{array}$} & \multirow{2}{*}{$\begin{array}{c}\text { Standardized } \\
\text { Coefficients } \\
\text { Beta } \\
\end{array}$} & \multirow[b]{2}{*}{$\mathrm{T}$} & \multirow[b]{2}{*}{ Sig. } \\
\hline & & B & Std. Error & & & \\
\hline 1 & (Constant) & 75,688 & 5,627 & & 13,450 &, 000 \\
\hline & &, 780 & ,291 & 246 & 2,679 & ,009 \\
\hline & ROE (\%) &,- 607 & 213 &,- 262 & $-2,849$ & 005 \\
\hline
\end{tabular}

a. Dependent Variable: DER (\%)

Sumber: Data sekunder diolah, 2018

Pada Tabel 11 dapat dilihat bahwa nilai signifikansinya sebesar 0,009 lebih kecil dari 0,05 , maka $\mathrm{H}_{1}$ diterima. Maka dapat disimpulkan bahwa terdapat pengaruh yang signifikan antara TAG pada DER di Perusahaan Industri Barang Konsumsi di BEI. Pada Standardized Coefficients menunjukkan nilai beta sebesar 0,246 memperlihatkan arah yang positif, nilai tersebut menunjukkan jika TAG meningkat maka DER juga akan meningkat dan juga sebaliknya.

Pada Tabel 11 dapat dilihat bahwa nilai signifikansinya sebesar 0,005 lebih kecil dari 0,05, maka $\mathrm{H}_{1}$ diterima Maka dapat disimpulkan bahwa terdapat pengaruh yang signifikan antara ROE pada DER di Perusahaan Industri Barang Konsumsi di BEI. Pada Standardized Coefficients menunjukkan nilai beta sebesar -0,262 yang memperlihatkan arah yang negatif, nilai tersebut meunjukkan jika ROE meningkat maka DER akan menurun dan juga sebaliknya. 
Tabel 12

Koefisien Regresi Model Kedua

Coefficients $^{\mathrm{a}}$

\begin{tabular}{|c|c|c|c|c|c|c|}
\hline \multirow[b]{2}{*}{ Model } & & \multicolumn{2}{|c|}{$\begin{array}{l}\text { Unstandardized } \\
\text { Coefficients }\end{array}$} & \multirow[t]{2}{*}{$\begin{array}{c}\text { Standardized } \\
\text { Coefficients }\end{array}$} & \multirow[b]{2}{*}{$\mathrm{t}$} & \multirow[b]{2}{*}{ Sig. } \\
\hline & & $\mathrm{B}$ & Std. Error & & & \\
\hline \multirow[t]{4}{*}{1} & (Constant) & ,932 &, 862 & & 1,082 & ,282 \\
\hline & TAG $(\%)$ &,- 025 & 028 &,- 084 &,- 892 & 374 \\
\hline & $\operatorname{ROE}(\%)$ &, 083 & 021 &, 380 & 4,027 & ,000 \\
\hline & $\operatorname{DER}(\%)$ & 019 & 009 & 206 & 2,133 & 035 \\
\hline
\end{tabular}

a. Dependent Variable: PBV (X)

Sumber: Data sekunder diolah, 2018

Pada Tabel 12 dapat dilihat bahwa nilai signifikansinya sebesar 0,374 lebih besar dari 0,05 , maka $\mathrm{H}_{1}$ ditolak. Hal ini menunjukkan bahwa terdapat pengaruh yang tidak signifikan antara TAG pada PBV di Perusahaan Industri Barang Konsumsi di BEI. Pada Standardized Coefficients menunjukkan nilai beta sebesar $-0,084$ yang memperlihatkan arah yang negatif, nilai tersebut meunjukkan bahwa jika TAG meningkat maka PBV akan mengalami penurunan dan sebaliknya.

Pada Tabel 12 dapat dilihat bahwa nilai signifikansinya sebesar 0,000 lebih kecil dari 0,05 , maka $\mathrm{H}_{1}$ diterima. Hal ini menunjukkan bahwa terdapat pengaruh yang signifikan antara ROE pada PBV di Perusahaan Industri Barang Konsumsi di BEI. Pada Standardized Coefficients menunjukkan nilai beta sebesar 0,380 yang memperlihatkan arah yang positif, nilai tersebut meunjukkan bahwa jika ROE meningkat maka PBV meningkat dan sebaliknya.

Pada Tabel 12 dapat dilihat bahwa nilai signifikansinya sebesar 0,035 lebih kecil dari 0,05 , maka $\mathrm{H}_{1}$ diterima. Hal ini menunjukkan bahwa terdapat pengaruh yang signifikan antara DER pada PBV di Perusahaan Industri Barang Konsumsi di BEI. Pada Standardized Coefficients menunjukkan nilai beta sebesar 0,206 
yang memperlihatkan arah yang positif, nilai tersebut meunjukkan bahwa jika DER meningkat maka PBV meningkat dan sebaliknya.

Berdasarkan dari hasil analisis jalur atau path analysis, secara tidak langsung akan dapat menghitung pengarung langsung, pengaruh tidak langsung dan pengaruh totalnya adalah sebagai berikut :

Tabel 13

Pengaruh Langsung, Pengaruh Tidak Langsung dan Pengaruh Total Variabel

\begin{tabular}{|c|c|c|c|}
\hline $\begin{array}{c}\text { Pengaruh } \\
\text { Variabel }\end{array}$ & $\begin{array}{l}\text { Pengaruh } \\
\text { Langsung }\end{array}$ & $\begin{array}{l}\text { Pengaruh Tidak } \\
\text { Langsung }\end{array}$ & Pengaruh Total \\
\hline $\mathrm{TAG} \rightarrow \mathrm{DER}$ & 0,246 & 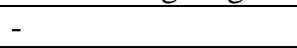 & - \\
\hline $\mathrm{ROE} \rightarrow \mathrm{DER}$ & $-0,262$ & - & - \\
\hline $\mathrm{TAG} \rightarrow \mathrm{PBV}$ & $-0,084$ & $\begin{array}{l}(0,246) \times(0,206) \\
=0,050\end{array}$ & $\begin{array}{l}-0,084+(0,050)=- \\
0,034\end{array}$ \\
\hline $\mathrm{ROE} \rightarrow \mathrm{PBV}$ & 0,380 & $\begin{array}{l}(-0,262) \times(0,206)= \\
0,053\end{array}$ & $\begin{array}{l}0,380+(0,053) \\
=0,433\end{array}$ \\
\hline $\mathrm{DER} \rightarrow \mathrm{PBV}$ & 0,206 & - & - \\
\hline
\end{tabular}

Sumber: Data sekunder diolah, 2018

Berdasarkan Tabel 13, pengaruh tidak langsung antara variabel Pertumbuhan Perusahaan (TAG) terhadap variabel Nilai Perusahaan (PBV) melalui variabel Struktur Modal (DER) adalah sebesar 0,050. Pengaruh langsung variabel Pertumbuhan Perusahaan (TAG) terhadap variabel Nilai Perusahaan (PBV) adalah sebesar -0,084. Hal tersebut menunjukkan bahwa struktur modal memiliki pengaruh pada pertumbuhan perusahaan terhadap nilai perusahaan karena $0,050>-0,084$. Jadi, semakin meningkatnya pertumbuhan perusahaan maka akan semakin besar hutang yang dibutuhkan perusahaan karena dana internal yang dimiliki perusahaan tidak cukup untuk membiayai perusahaan yang sedang tumbuh. Jika pertumbuhan perusahaan meningkat maka nilai perusahaan juga akan meningkat. 
Berdasarkan Tabel 13, pengaruh tidak langsung antara variabel Profitabilitas (ROE) terhadap variabel Nilai Perusahaan (PBV) melalui variabel Struktur Modal (DER) adalah sebesar 0,053. Pengaruh langsung variabel Profitabilitas (ROE) terhadap variabel Nilai Perusahaan (PBV) adalah sebesar 0,380. Hal tersebut menunjukkan bahwa meningkatnya struktur modal tidak memiliki pengaruh pada profitabilitas terhadap nilai perusahaan karena $0,053<0,380$. Jadi, semakin besar profitabilitas perusahaan maka perusahaan akan lebih memilih menggunakan profitabilitasnya terlebih dahulu daripada harus menggunakan hutang dalam membiayai operasional perusahaan sehingga dapat meningkatkan nilai perusahaan.

Hasil dari penelitian yang dilakukan menjelaskan jika Pertumbuhan Perusahaan (TAG) memiliki pengaruh yang positif dan signifikan pada Struktur Modal (DER) di Perusahaan Industri Barang Konsumsi di Bursa Efek Indonesia tahun 2014-2016. Hasil penelitian tersebut selaras dengan hipotesis pertama yang menyatakan Pertumbuhan Perusahaan memiliki pengaruh yang positif dan signifikan pada Struktur Modal. Pengaruh positif dan signifikan tersebut menjelaskan bahwa semakin meningkatnya pertumbuhan perusahaan maka struktur modal juga meningkat. Perusahaan yang memiliki tingkat pertumbuhan aktiva tinggi harus lebih banyak menggunakan dana eksternal, karena jika pertumbuhan perusahaan tinggi maka kebutuhan dana untuk membiayai ekspansi semakin besar. Perusahaan-perusahaan dengan tingkat pertumbuhan yang lambat akan menggunakan sedikit hutang dibandingkan dengan perusahaan yang pertumbuhannya lebih cepat (Hermuningsih, 2013). Hasil penelitian ini juga 
sejalan dengan penelitian Akinyomi dan Olagunju (2013), Daskalakis et al. (2014), dan Karacaer et al. (2016).

Hasil dari penelitian yang dilakukan menjelaskan jika Profitabilitas (ROE) memiliki pengaruh yang negatif dan signifikan pada Struktur Modal (DER) di Perusahaan Industri Barang Konsumsi di Bursa Efek Indonesia tahun 2014-2016. Hasil penelitian tersebut selaras dengan hipotesis kedua yang menyatakan Profitabilitas memiliki pengaruh yang negatif dan signifikan terhadap Struktur Modal. Pengaruh positif dan signifikan tersebut menunjukkan bahwa semakin meningkatnya pertumbuhan perusahaan maka struktur modal juga meningkat. Pengaruh negatif dan signifikan tersebut menjelaskan bahwa semakin meningkatnya profitabilitas maka struktur modalnya akan mengalami penurunan. Perusahaan yang profitabilitasnya tinggi akan lebih sedikit menggunakan utang karena perusahaan sudah memiliki laba ditahan yang tinggi untuk mendanai kegiatan perusahaannya. Perusahaan dengan kondisi keuangan yang baik akan lebih sedikit meminjam uang walaupun mempunyai kesempatan untuk meminjam uang yang lebih banyak (Sartono, 2014:76). Hasil penelitian ini juga sejalan dengan penelitian Hermuningsih (2013), Daskalakis, et al. (2014), dan Karacaer et al. (2016).

Hasil dari penelitian yang dilakukan menjelaskan jika Pertumbuhan Perusahaan (TAG) tidak memiliki pengaruh pada Nilai Perusahaan (PBV) di Perusahaan Industri Barang Konsumsi di Bursa Efek Indonesia tahun 2014-2016. Hasil penelitian tersebut menolak hipotesis ketiga yang menyatakan Pertumbuhan Perusahaan berpengaruh positif dan signifikan terhadap Nilai Perusahaan. Tidak 
signifikan tersebut menunjukkan bahwa apabila pertumbuhan perusahaan meningkat maka nilai perusahaan tidak akan mengalami peningkatan. Hal tersebut terjadi karena jika pertumbuhan perusahaan tinggi maka dana yang dibutuhkan untuk kegiatan operasional perusahaan juga tinggi. Saat perusahaan fokus pada pertumbuhan perusahaan maka perusahaan akan menggunakan seluruh dananya untuk membiayai pertumbuhan perusahaan tersebut dan tidak memperhatikan kesejahteraan pemegang saham. Saat hal tersebut terjadi maka dampaknya adalah turunnya nilai perusahaan (Meidiawati, 2016). Hasil penelitian ini juga sejalan dengan penelitian Fau (2015), Riaz dan Qasim (2016), dan Dewi dan Sudiartha (2017).

Hasil dari penelitian yang dilakukan menjelaskan jika Profitabilitas (ROE) memiliki pengaruh yang positif dan signifikan pada Nilai Perusahaan (PBV) di Perusahaan Industri Barang Konsumsi di Bursa Efek Indonesia tahun 2014-2016. Hasil penelitian tersebut selaras dengan hipotesis keempat yang menyatakan Profitabilitas memiliki pengaruh yang positif dan signifikan pada Nilai Perusahaan. Pengaruh positif dan signifikan tersebut menunjukkan bahwa semakin meningkatnya profitabilitas perusahaan maka nilai perusahaan juga akan meningkat. Nilai profitabilitas yang tinggi menunjukkan kinerja perusahaan meningkat dan diperkirakan perusahaan mempunyai prospek masa depan yang baik sehingga permintaan akan saham perusahaan juga naik. Meningkatnya permintaan akan menaikkan harga saham,sehingga nilai perusahaan akan meningkat (Susanto, 2016). Hasil penelitian ini juga sejalan dengan penelitian 
Lestari dan Armayah (2016), Riaz dan Qasim (2016), dan Dewi dan Sudiartha (2017).

Hasil dari penelitian yang dilakukan menjelaskan jika Struktur Modal (DER) memiliki pengaruh yang positif dan signifikan pada Nilai Perusahaan (PBV) di Perusahaan Industri Barang Konsumsi di Bursa Efek Indonesia tahun 2014-2016. Hasil penelitian tersebut selaras dengan hipotesis kelima yang menyatakan Struktur Modal memiliki pengaruh yang positif dan signifikan pada Nilai Perusahaan. Pengaruh positif dan signifikan tersebut menunjukkan bahwa semakin meningkatnya struktur modal maka nilai perusahaan juga akan meningkat. Jika dibandingkan antara dua perusahaan, dimana perusahaan menghasilkan laba yang sama, tetapi salahsatunya berhutang dan harus membayarkan bunganya sedangkan satunya tidak berhutang, maka pajak penghasilan (income tax) yang dibayarkan perusahaan yang membayar bunga akan lebih kecil. Penghematan pembayaran pajak tersebut dapat menjadi keuntungan bagi perusahaan. Nilai perusahaan saat tidak berhutang akan menjadi rendah daripada nilai perusahaan yang berhutang. Hal tersebut sesuai dengan teori Modigliani dan Miller dalam keadaan ada pajak (Husnan dan Pudjiastuti, 2012:269). Hasil penelitian ini juga sejalan dengan penelitian Rehman (2016), Meidiawati (2016) dan Riaz dan Qasim (2016).

\section{SIMPULAN DAN SARAN}

Berdasakan hasil dari penelitian yang sudah dilakukan, maka dapat disimpulkan Pertumbuhan Perusahaan berpengaruh positif dan signifikan pada 
Struktur Modal di Perusahaan Industri Barang Konsumsi di Bursa Efek Indonesia tahun 2014-2016. Profitabilitas memiliki pengaruh negatif dan juga signifikan pada Struktur Modal di Perusahaan Industri Barang Konsumsi di Bursa Efek Indonesia tahun 2014-2016. Pertumbuhan Perusahaan tidak memiliki pengaruh pada Nilai Perusahaan di Perusahaan Industri Barang Konsumsi di Bursa Efek Indonesia tahun 2014-2016. Profitabilitas berpengaruh positif dan signifikan pada Nilai Perusahaan di Perusahaan Industri Barang Konsumsi di Bursa Efek Indonesia tahun 2014-2016. Struktur Modal memiliki pengaruh yang positif dan juga signifikan pada Nilai Perusahaan di Perusahaan Industri Barang Konsumsi di Bursa Efek Indonesia tahun 2014-2016. Struktur modal dapat mempengaruhi hubungan antara Pertumbuhan Perusahaan pada Nilai Perusahaan. Struktur Modal tidak dapat mempengaruhi hubungan antara Profitabilitas pada Nilai Perusahaan.

Adapun saran yang dapat peneliti berikan bagi peneliti selanjutnya yang ingin meneliti variabel yang sama disarankan untuk meneliti pada sektor yang berbeda dan dengan periode penelitian yang lebih lama. Disarankan juga untuk menambah beberapa variabel yang mempengaruhi nilai perusahaan. Sedangkan bagi manajemen perusahaan khususnya pada sektor industri barang konsumsi disarankan untuk memperhatikan variabel pertumbuhan perusahaan, profitabilitas sebelum menetapkan kebijakan penggunaan struktur modalnya, karena hal tersebut juga berpengaruh terhadap nilai perusahaan. Caranya dengan melihat perkembangan pertumbuhan perusahaan dan profitabilitas perusahaan, karena dengan melihat perkembangannya maka perusahaan dapat mengambil keputusan 
yang tepat dalam menentukan penggunaan struktur modalnya yang akan berpengaruh terhadap nilai perusahaan tersebut.

\section{REFERENSI}

Ahmadimousaabad, Aiyoub., Melati Ahmad Anuar., Saudah Sofian dan Agha Jahanzeb. 2013. Capital Structure Decisions and Determinants: An Empirical Study in Iran. International Research Journal of Applied and Basic Sciencess, 5(7):891-896.

Akinyomi, Oladele John and Olagunju, Adebayo. 2013. Determinants of Capital Structure in Nigeria. International Journal of Innovation and Applied Studies, 3(4):999-1005.

Anzlina, Corry Winda dan Rustam. 2013. Pengaruh Tingkat Likuiditas, Solvabilitas, Aktivitas, dan Profitabilitas Terhadap Nilai Perusahaan Pada Perusahaan Real Estate Dan Property Di BEI Tahun 2006 - 2008. Jurnal Ekonom,16(2):1-18.

Ayako, Aloys and Wamalwa, Fidelis. 2015. Determinants of Firm Value in Kenya: Case of Commercial Banks Listed at the Nairobi Securities Exchange. Applied Finance and Accounting, 1(2):129-142.

Brigham dan Gapenski. 2006. Intermediate Financial Management. New York: The Dryden Press.

Brigham, Eugene F. dan Joel F. Houston (Ali Akbar Yulianto, Penerjemah). 2011. Dasar-dasar Manajemen Keuangan. Edisi 1. Jakarta: Salemba Empat.

Cortez, M.A and Susanto, Stevie. 2012. The Determinants Of Corporate CapitalStructure: Evidence From JapaneseManufacturing Companies. Journal of International Business Research,11(3):121-134.

Daskalakis, Nikolas., Eriotis, Nikolas., Thanou, Eleni and Vasiliou, Dimitrios. 2014. Capital Structure and Size: New Evidence Across the Broad Spectrum of SMEs. Managerial Vinance, 40(12):1207-1222.

Dewi, D.A.I.Y.M dan Sudiartha, G.M. 2017. Pengaruh Profitabilitas, Ukuran Perusahaan dan Pertumbuhan Aset Terhadap Struktur Modal dan Nilai Perusahaan. E-Jurnal Manajemen Unud, 6(4):2222-2252.

Dewi, P. Y. S., Yuniarta, G. A dan Atmadja, A.W.T. 2014. Pengaruh Struktur Modal, Pertumbuhan Perusahaan dan Profitabilitas Terhadap Nilai 
Perusahaan Pada Perusahaan LQ 45 di BEI Periode 2008-2012. e-Journal S1 Ak Universitas Pendidikan Ganesha, 2 (1):1-10.

Fau, Nia Rositawati. 2015. Pengaruh Struktur Modal, Pertumbuhan Perusahaan, Ukuran Perusahaan dan Profitabilitas Terhadap Nilai Perusahaan Pada Perusahaan Manufaktur yang Terdaftar Di Bursa Efek Indonesia. Skripsi. Fakultas Ekonomi Universitas Negeri Yogyakarta.

Febrianti, Meiriska. 2012. Faktor - Faktor Yang Mempengaruhi Nilai Perusahaan Pada Industri Pertambangan Di Bursa Efek Indonesia. Jurnal Bisnis dan Akuntansi, 14(2):141-156.

Gamaliel, Joshua., dan Luh Komang Sudjarni. 2015. Pengaruh Profitabilitas, Ukuran Perusahaan, dan Ukuran Perusahaan dan Struktur Aktiva Terhadap Struktur Modal Pada Perusahaan Transportasi Di BEI. E-Jurnal Manajemen Universitas Udayana, 4(1):59-74.

Herawati, Titin. 2014. Pengaruh Kebijakan Dividen, Kebijakan Hutang dan Profitabilitas Terhadap Nilai Perusahaan. Jurnal Akuntansi Universitas Negeri Padang.

Hermuningsih, Sri. 2013. Pengaruh Profitabilitas, Growth Oppurtunity, Struktur Modal Terhadap NIlai Perusahaan Publik Di Indonesia. Buletin Ekonomi Moneter dan Perbankan, 16(2):127-148.

Hestinoviana, Vidyanita., Suhadak and Handayani, Siti Ragil. 2012. The Influence of Profitability, Solvability, Asset Growth and Sales Growth Toward Firm Value (Empirical Study on Mining Companies Which Listed on Indonesia Stock Exchange. Journal University, 1(1):1-11.

Husnan, Suad dan Pudjiastuti, Eny. 2012. Dasar-Dasar Manajemen Keuangan. Edisi Keenam. Yogyakarta: UPP STIM YKPN.

Hoque, Jahirul., Hossain, Ashraf., and Hossain, Kabir. 2014. Impact Of Capital Structure Policy On Value Of The Firm - A Study On Some Selected Corporate Manufacturing Firms Under Dhaka Stock Exchange. ECOFORUM, 3(5):77-84.

Juhandi, dkk. 2013.TThe Effects of Internal factors and Stock Ownership Structure on Dividend Policy on Company's Value [A Study on Manufacturing Companies Listed on the Indonesia Stock Exchange (IDX)]. International Journal of Business and Management Invention, 2(11):6-18.

Karacaer, Semra., Temiz, Huseyin., and Gulec, O.F. 2016. Determinants of Capital Structure: An Application on Manufacturing Firms in Borsa 
Istanbul. International Academic Journal of Accounting and Financial Management, 3(2):47-59.

Kartika, I Komang Suarnata., dan Made Dana. 2015. Analisis Pengaruh Profitabilitas, Likuiditas, Ukuran Perusahaan, dan Tingkat Pertumbuhan Terhadap Struktur Modal Perusahaan Food And Baverage yang terdaftar di BEI. E-Jurnal Manajemen Universitas Udayana, 4(3):606-625.

Kuncoro, Engkos Achmad, dan Riduan. 2011. Cara Menggunakan dan Memakai Path Analysis. Bandung: CV Alfabeta

Kusumajaya, Dewa Kadek Oka. 2011. Pengaruh Struktur Modal dan Pertumbuhan Perusahaan Terhadap Profitabilitas dan Nilai Perusahaan Pada Perusahaan Manufaktur Di Bursa Efek Indonesia. Tesis. Universitas Udayana.

Lestari, Siti Ayu and Armayah, Mursalim. 2016. Profitability and Company Value: Empirical Study of Manufacture Companies in Indonesia Period 2009 - 2014. Information Management and Business Review, 8(3): 6-10.

Li-Ju, Chen and Shun-Yu., Chen. 2011. The Influence Of Profitability On Firm Value With Capital StructureAs The Mediator And Firm Size And Industry As Moderators. Investment Management and Financial Innovations, 8(3):121-129.

Meidiawati, Karina. 2016. Pengaruh Size, Growth, Profitabilitas, Struktur Modal, Kebijakan Dividen Terhadap Nilai Perusahaan. Jurnal Ilmu dan Riset Akuntansi, 5(2):1-16.

Ogbulu, Onyemachi Maxwell and Emeni., Francis Kehinde. 2012. Capital Structure and Firm Value: Empirical Evidence from Nigeria.International Journal of Bussiness and Social Science, 3(19):252-261.

Rehman, O.U. 2016. Impact of Capital Structure and Dividend Policy on Firm Value. Journal of Poverty, Investment and Development, 21:40-57.

Riaz, Majid., and Qasim, Muhammad. 2016. Islamic Microfinance Institution: The Capital Structure, Growth, Performance And Value Of The Firm In Pakistan. Journal of ISOSS, 2(1):97-101.

Sartono, A. 2014. Manajemen Keuangan Teori Dan Aplikasi, Edisi 4, Yogyakarta: BPFE.

Shun-Yu, Chen., and Li-Ju, Chen. 2011. Capital structure determinants: An empirical study in Taiwan. African Journal of Business Management, 5(27):10974-10983. 
Sudiani, N.K.A dan Darmayanti, N.P.A. 2016. Pengaruh Profitabilitas, Likuiditas, Pertumbuhan, dan Investment Opportunity Set Terhadap Nilai Perusahaan. E-Jurnal Manajemen Unud, 5 (7):4545-4547.

Susanto, Edy. 2016. Pengaruh Profitabilitas, Kepemilikan Manajerial, Dan Pertumbuhan Perusahaan (Growth) Terhadap Struktur Modal Dan Nilai Perusahaan. Jurnal STIE SEMARANG, 8(3):1-20.

Ulum, Achmad Saiful. 2015. The Influence Of Profitability and Capital Structure on Firm Value (Study on Manufacturing Industries Listed at Indonesia Stock Exchange for Periods 2008-2012). Media Mahardhika, 14(1):79-97.

Utama, Made Suyana. 2014. Aplikasi Analisis Kuantitatif. Denpasar: Fakultas Ekonomi dan Bisnis Universitas Udayana.

Wardhani, Guniarti Indah. 2016. Pengaruh Profitabilitas, Pertumbuhan Perusahaan, Ukuran Perusahaan, Struktur Aktiva dan Likuiditas Terhadap Struktur Modal (Studi pada Perusahaan Manufaktur di Bursa Efek Indonesia Tahun 2010- 2012). Jurnal Manajemen Universitas Muhammadiyah Yogyakarta, 1(1):1-16.

Wiagustini, Ni Luh Putu. 2010. Dasar-dasar Manajemen Keuangan. Udayana: University Press. 